\title{
Chronic bronchitis and airflow obstruction is associated with household cooking fuel use among never-smoking women: a community-based cross-sectional study in Odisha, India
}

\author{
Asmi Panigrahi ${ }^{1}$ and Bijaya K. Padhi ${ }^{2^{*}}$ (i)
}

\begin{abstract}
Background: The use of solid biomass as cooking fuel could be a potential risk factor for chronic bronchitis (CB) and airflow obstruction (AFO) among never-smoking women. The disease burden in India among women is generally underestimated due to limited population-based epidemiological investigations. The aim of the study was to determine the prevalence of CB and AFO among never-smoking women, and its association with household cooking fuel use.

Methods: We conducted a community-based cross-sectional study with a representative study sample $(N=1120)$ in Odisha, India during 2013-14. Study participants, never-smoking women aged 18-49 years, were recruited randomly from the population census. Trained community health volunteers administered a validated questionnaire that aligned with the standards of the Burden of Obstructive Lung Disease (BOLD) initiative and conducted spirometry. Prevalence estimates of CB (defined as "cough with productive of sputum for at least 3 months of the year for at least 2 years") and AFO (pre-bronchodilator forced expiratory volume in $1 \mathrm{~s}$ (FEV1)/forced vital capacity $(F V C)<0.7)$ was estimated. Indoor PM2.5 exposure data were collected from a subset of 130 of the total 1120 homes in the study settings. Multivariable regression models were used to estimate the associated risk factors.

Results: Prevalence of CB and AFO were 7.3 and $22.4 \%$ respectively among the study participants. Of the study participants, 31\% used exclusive liquefied petroleum gas, 18\% used mixed fuel and $51 \%$ exclusively used solid biomass fuel for household cooking. In adjusted analysis, both CB (odds ratio 1.96, 95\% Cl: 1.06-3.64; $p=0.031$ ) and AFO (OR 5.55, 95\% Cl: 3.51-8.78; $p<0.001$ ) were found to be associated with cooking with solid biomass fuel. Interquartile range increases in PM2.5 was associated with significantly lower FEV1/FVC ratio.

Conclusions: The study highlights that the estimates of population burden of $C B$ and AFO are much higher than shown in previous epidemiological studies, and that cooking fuel type and time spent on cooking were associated with increased chronic bronchitis as well as decreased lung function as measured by FEV1/FCV ratios. To most accurately understand the current burden of disease and most effectively prevent an escalation in the future disease burden, further epidemiological investigations are warranted.
\end{abstract}

Keywords: Airflow obstruction, Chronic bronchitis, Solid biomass fuel, Household air pollution, PM2.5, Lung function, Liquefied petroleum gas

\footnotetext{
* Correspondence: bkpadhi@aiph.ac.in

${ }^{2}$ Center for Environmental and Occupational Health, AIPH University,

Bhubaneswar, India

Full list of author information is available at the end of the article
}

(c) The Author(s). 2018 Open Access This article is distributed under the terms of the Creative Commons Attribution 4.0 International License (http://creativecommons.org/licenses/by/4.0/), which permits unrestricted use, distribution, and reproduction in any medium, provided you give appropriate credit to the original author(s) and the source, provide a link to the Creative Commons license, and indicate if changes were made. The Creative Commons Public Domain Dedication waiver (http://creativecommons.org/publicdomain/zero/1.0/) applies to the data made available in this article, unless otherwise stated. 


\section{Background}

Globally, chronic respiratory disease is a major public health problem [1]. A recent medical survey conducted in India concluded that $50 \%$ of patients report to clinics with respiratory problems [2]. Under the umbrella of lung diseases, chronic bronchitis (CB) has been shown to have the most significant clinical impact regarding both morbidity as well as the quality of life [3-6]. CB has been defined as chronic cough with sputum production for at least 3 months per year for two consecutive years, and varies across epidemiological investigations [7]. CB has been considered as a surrogate for a diagnosis of chronic respiratory diseases for epidemiological purposes [8]. The prevalence of $\mathrm{CB}$ in adults $>35$ years or older in India has been reported to be $3.49 \%(4.29 \%$ in males and $2.7 \%$ in females) [9]. Lung function measurement by spirometry is the preferred modality for establishing an accurate diagnosis of airflow obstruction (AFO). However, empirical evidence of the burden of AFO in India, especially spirometry-based general population data, is lacking. Further, most healthcare facilities have limited pulmonary care expertise and clinical capacity to quantify the burden of AFO, and instead rely on symptomatic data reported by patients or their caregivers. With only a few exceptions, the result is that the existing estimates of mortality and morbidity related to AFO in India have been derived either from infrequent national hospital surveys, or extrapolation from statistical models $[2,9,10]$. Thus, while the significance and implications of AFO have been established, there remains a gap in measuring the true burden of disease in India.

Furthermore, much is known about the strategies for mitigating the disease burden [10], yet chronic respiratory diseases are still poised to emerge as a leading cause of morbidity and mortality in low-and-middle-income countries in the near future [11-14]. Though the primary risk factor for $\mathrm{CB}$ is smoking, numerous studies have been reporting $\mathrm{CB}$ among never-smokers, suggesting that other risk factors may exist [7, 15-18].

About 3 billion people worldwide, including 6.5 million Americans and nearly 700 million Indians, continue to use solid biomass fuel to meet their household energy needs [19-21]. Using solid fuels in open fires or stoves at home while cooking or heating produces extremely toxic pollutants including fumes containing a high concentration of inhalable particulate matters (PM) that can range from 300 to $3000 \mu \mathrm{g} / \mathrm{m}^{3}$, sometimes reaching levels as high as $10,000 \mu \mathrm{g} / \mathrm{m}^{3}$. This accounts for 4 million annual deaths worldwide [22-24]. Household air pollution resulting from combustion of solid biomass fuel could be a potential risk factor for $\mathrm{CB}$ and $\mathrm{AFO}$ among never smoking women, this relationship largely unexplored in India. We, therefore designed a community-based study to measure the prevalence of CB and AFO in an eastern state in India, as well as investigate the association between household cooking fuel use and the disease burden.

\section{Methods \\ Study setting}

This community-based cross-sectional study was carried out in the rural setting of Odisha, an eastern state in India, home to 41.9 million people. The state has one of the highest infant mortality (51 per 1000 live births) and maternal mortality (235 per 100,000 live births) rates in India [25]. The study was conducted in two blocks of Khordha districts (rural coastal settings), which have a population of about 200,000 individuals with approximately 30,000 women of reproductive age (13-49 years). Villages are densely populated and located at an altitude of $41.2 \mathrm{~m}$. Inhabitants in the study site subsist on irrigated agriculture and work in government offices and other small service industries.

\section{Study design}

A community-based cross-sectional study was designed based on a priori hypothesis, and the study participants, never-smoking women and primary cook in the household, aged 18-49 years were recruited randomly from the population census developed by the study institute (Asian Institute of Public Health) (Fig. 1). The sample size of 1117 was estimated to obtain a 95\% confidence interval $(\mathrm{CI})$ of $\pm 1.0 \%$ around a prevalence estimate of $3 \%$ [9]. We recruited 1120 individuals, anticipating some non-response among the study participants for detailed household survey, including lung function measurements and respiratory symptoms assessment. The sample size was calculated using the OpenEpi tools [26].

\section{Data collection tools}

Our study is in accordance with the Burden of Obstructive Lung Disease (BOLD) initiative [8]. We used the International Union Against Tuberculosis and Lung Disease (IUATLD) English questionnaire [27] to study the prevalence of chronic airflow diseases in the study population. The same questionnaire has been validated and tested for its reliability in the "Indian study on epidemiology of asthma, respiratory symptoms and chronic bronchitis in adults (INSEARCH)" in the local context [9]. The study questionnaire included questions on respiratory disease symptoms as well as questions on socio-demographics and environmental exposures. The questions administered covered study participants' history of chronic bronchitis (cough and phlegm for $\geq 3$ months of the year for $\geq 2$ years), chronic cough (with/without phlegm) and chronic phlegm (with/without cough). Based on household cooking fuel preferences, we categorized the households into three groups "LPG: households used exclusively Liquefied Petroleum Gas (LPG) for cooking"; "mixed fuel: household 


\section{Population Survey \\ Rural settings of Odisha, India}

\section{Target Population}

30,000 women / 200,000 population

Assessed for eligibility: Never-smoking women, $18-49$ years age and primary cook

\section{Random sampling [1120 eligible women]}

\section{Study Population $¥$}

1120 never smoking women recruited in the study

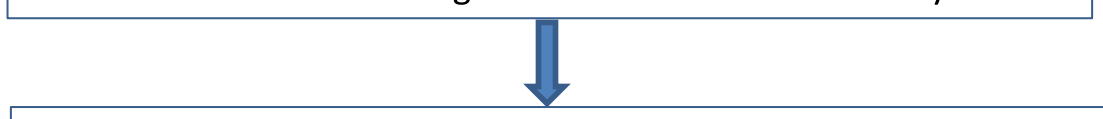

Completed household survey including respiratory health questionnaire $(N=1120)$

Completed acceptable spirometry $(\mathrm{N}=1056)$

Household air pollution study ( $N=130)$; [LPG ( $N=37)$; Mixed fuel ( $N=45)$; Biomass $(N=48)]$

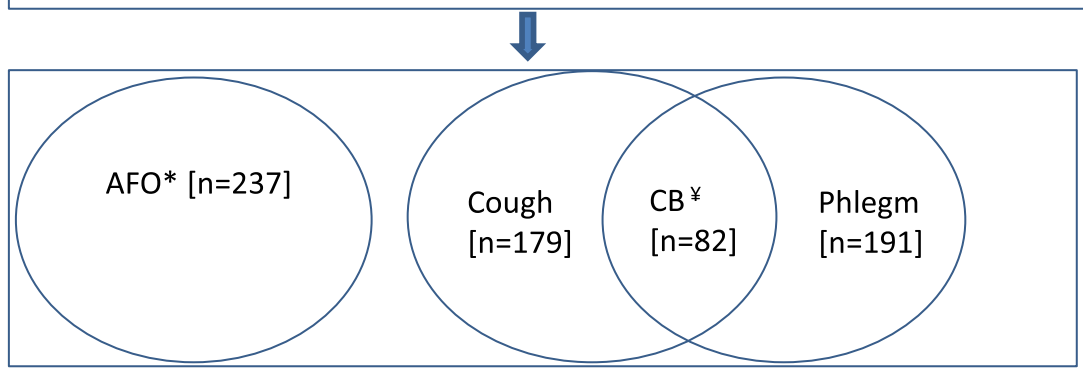

*Airflow obstruction (AFO) was based on FEV1/FVC $<70 \%$ predicted; ${ }^{\ddagger}$ Chronic bronchitis (CB): cough with phlegm for more than three months in a year for 2 or more consecutive years

Fig. 1 Schematic representation of sampling scheme and study findings used a combination of fuel (LPG, kerosene, electricity, and solid biomass) for cooking" and; "solid biomass fuel: household used exclusively biomass fuel for cooking".

Our primary outcome measure was to study the prevalence of $\mathrm{CB}$ and AFO. We diagnosed $\mathrm{CB}$ in the study population on the basis of affirmative responses to the IUATLD questions, which consisted of the presence of cough with expectoration for more than 3 months in a year for two or more consecutive years $[9,27]$.

\section{Spirometry and definition of AFO}

Spirometric testing was carried out using a MicroLoop spirometer (CareFusion, USA) by a trained community health supervisor and conducted in accordance with American Thoracic Society/ European Respiratory Society guidelines. All spirometry was conducted at the household of the study participants and performed during the day time (9:00 AM-2:00 PM). Participants were instructed to breathe in and out through the mouthpiece as deeply and quickly as possible while a nose clip was applied in a sitting position. We used south Indian reference values for spirometry [28]. The spirometer acquired the forced vital capacity (FVC), forced expiratory volume in $1 \mathrm{sec}$ (FEV1), and the ratio of (FEV1)/(FVC). The device records the best performance of the three successful/acceptable efforts. Since post-bronchodilator measurements were not obtained we categorised AFO status using the modified Global Initiative for Chronic Obstructive Lung Disease (GOLD) criteria (GOLD grade $\geq 1$ : FEV1/ FVC < 0.7; GOLD $\geq 2$ : FEV1/FVC $<0.7$ and FEV1/ predicted FEV1 $<0.8 ;$ GOLD $\geq 3$ : FEV1/FVC $<0.7$ and FEV1/predicted FEV1<0.5) [29]. Participant's age, height, and weight were collected at the time of 
spirometry. Weight was measured using an electronic balance (calibrated daily), and height was recorded using a metal tape with height mark on the wall. Of the 1120 women who participated in the survey, 1056 could perform the spirometry adequately for further analysis.

\section{Environmental exposure monitoring}

Household PM2.5 exposure assessment was conducted in a subset $(N=130)$ of the study households selected conveniently according to the household cooking behavior. PM2.5 was monitored using Minivol (Airmatrix) sampler operated at $10 \mathrm{~L} / \mathrm{min}$ and collected particles on a $47 \mathrm{~mm}$ quartz filter (Whatman International, Ltd., Maidstone, England). Before mounting the filter paper, the serial number was recorded and the filter paper equilibrated overnight in ambient temperature and humidity. A calibrated micro-balance (Mettler Instrument Corp., Hightstown, NJ) was used to weigh the filter papers with a precision of $\pm 5.0 \mu \mathrm{g}$. A thorough quality inspection was conducted to identify any tears, folds, and other imperfections. Sampling was conducted at the center of the living room and placed $1.5 \mathrm{~m}$ above the ground, and at least $0.5 \mathrm{~m}$ away from walls. After sampling, the particle-loaded filter papers were placed in a sealed container and transported to the laboratory for further analysis. Total mass concentration of each filter was estimated by weighing the particle-loaded filters following a $24 \mathrm{~h}$ equilibration period. The sampling was carried out for $12 \mathrm{~h}(8.0 \mathrm{am}-8.0 \mathrm{pm})$ and monitored only once in the study households.

\section{Data analysis}

A database was created using a custom-designed Epi-info platform. Descriptive statistics (frequency, means, and standard deviations) were calculated and cross-tabulated with household fuel use. Group comparisons were performed using the chi-square $\left(\mathrm{x}^{2}\right)$ test (for categorical variables) and ANOVA (for continuous variables). Principal component analysis with varimax rotation was used for computing a socio-economic status (SES) index [30] from the household characteristics and asset data. Based on the distribution of the SES indices, the households were then divided into three groups (tertiles) of socio-economic status: low, medium, and high.

Unadjusted and adjusted odds ratios and 95\% CIs were computed using logistic regression models to estimate the associated risk factors. All multivariable regression models were performed using a priori hypotheses. Results from all analyses were considered significant at a $p$-value of 0.05 . All data analysis including production of tables and figures were performed using Stata ${ }^{\circ}$ Software version SE 13.0 (College Station, TX, USA).

\section{Results}

All 1120 participants completed the survey. Of the 1120 , spirometry could be adequately performed in 1056 participants. Table 1 shows the characteristics of the participants stratified by participant's household cooking fuel types. Of the study participants only $31 \%$ of women cooked exclusively with a cleaner fuel (LPG), approximately half of them used solid biomass fuel (51\%), and $18 \%$ had used mixed fuel (LPG, electricity, and solid biomass). The mean age of participants was 30 years, and the mean BMI was $23.3 \pm 3.5$. About $6.8 \%$ of the solid biomass users and $10 \%$ of total study participants were from higher socioeconomic status. Most of the participants completed their primary education (96.5\%) with less variation across groups. Ninety-four percent of the respondents were homemakers, and $66 \%$ of them were married. 5.6\% of participants were exposed to environmental tobacco smoke in childhood or adulthood. Only $12 \%$ households had a separate kitchen, and only $16 \%$ of the kitchens were ventilated. One percent of participants had a family history of asthma.

The 5th to 95th percentile ranges of the household exposure PM2.5 distribution is shown in Fig. 2, ranging from 40 to $300 \mu \mathrm{g} / \mathrm{m}^{3}$ (vs. mean of $148.6 \mu \mathrm{g} / \mathrm{m}^{3}$ ), demonstrating the considerable variation in fine particle exposure across the households. The median PM2.5 levels were $87.8 \mu \mathrm{g} / \mathrm{m}^{3}, 132.2 \mu \mathrm{g} / \mathrm{m}^{3}$, and $230.6 \mu \mathrm{g} / \mathrm{m}^{3}$ in LPG, mixed fuel and solid biomass fuel burning household respectively (Fig. 2).

The prevalence of chronic bronchitis, including other respiratory symptoms, is shown in Table 2 . The overall prevalence of chronic bronchitis was 7.3\% (82 of the 1120 participants). The CB prevalence was lower $(n=15$, 4.3\%) among LPG users than mixed fuel $(n=17,8.3 \%)$ and solid biomass fuel $(n=50,8.7 \%)$ user groups. A significant difference of prevalence of wheezing was observed across study groups and was higher among biomass users (12.7\%).

Table 3 presents the analysis of multivariable logistic regression model. Household cooking fuel use was found to be associated with $\mathrm{CB}$ in the multivariable model. Solid biomass fuel users had a significantly higher risk $(\mathrm{AOR}=1.96 ; 95 \% \mathrm{CI}: 1.06-3.64)$ of $\mathrm{CB}$. Households practicing cooking with mixed fuel were not found to have any protective effect against $\mathrm{CB}(\mathrm{AOR}=1.85$; $95 \%$ CI: 0.87-3.89).

The prevalence of AFOs are shown in Table 4 by current cooking fuel. Of the 1056 participants who provided acceptable spirometry, $22.4 \%$ of them were found to be at risk of AFO (FEV1/FVC $<70 \%$ predicted). The extent of obstruction was higher among biomass fuel users (31\%).

Table 5 shows odds ratios for associations between AFO and household cooking fuel use. In regression 
Table 1 Socio-demographic characteristics of the Study Population $(N=1120)$

\begin{tabular}{|c|c|c|c|c|c|}
\hline Characteristics & $\begin{array}{l}\text { All participants } \\
(N=1120)\end{array}$ & $\begin{array}{l}\text { Liquefied petroleum gas user } \\
(N=344)\end{array}$ & $\begin{array}{l}\text { Mixed fuel user } \\
(N=203)\end{array}$ & $\begin{array}{l}\text { Solid biomass fuel user } \\
(N=573)\end{array}$ & $p$-value \\
\hline \multicolumn{6}{|c|}{ Anthropometrics: Age (years), Height (cm) and Weight (Kg) } \\
\hline Age $($ mean $\pm S D)$ & $30.44 \pm 6.86$ & $31.06 \pm 6.92$ & $31.64 \pm 7.26$ & $29.63 \pm 6.58$ & $<0.001$ \\
\hline Height (mean \pm SD) & $154.67 \pm 8.35$ & $152.83 \pm 8.04$ & $155.48 \pm 7.86$ & $155.48 \pm 8.54$ & $<0.001$ \\
\hline Weight (mean \pm SD) & $55.50 \pm 7.67$ & $53.84 \pm 7.79$ & $55.33 \pm 7.50$ & $56.56 \pm 7.49$ & $<0.001$ \\
\hline BMI (mean \pm SD) & $23.30 \pm 3.50$ & $23.14 \pm 3.49$ & $22.96 \pm 3.26$ & $23.53 \pm 3.57$ & 0.079 \\
\hline \multicolumn{6}{|l|}{ Marital Status [n, \%] } \\
\hline Married & $745(66.5)$ & $228(66.2)$ & $138(67.9)$ & $379(66.1)$ & \multirow[t]{2}{*}{0.887} \\
\hline Unmarried & $375(33.4)$ & $116(33.7)$ & $65(32.0)$ & $194(33.8)$ & \\
\hline \multicolumn{6}{|c|}{ Socio-economic status (SES) Indices ${ }^{\mathrm{a}}[\mathrm{n}, \%]$} \\
\hline Low & $114(10.18)$ & $8(2.33)$ & $22(10.84)$ & $84(14.66)$ & \multirow[t]{3}{*}{$<0.001$} \\
\hline Middle & $895(79.91)$ & $279(81.10)$ & $166(81.77)$ & $450(78.53)$ & \\
\hline High & $111(9.91)$ & $57(16.57)$ & $15(7.39)$ & $39(6.81)$ & \\
\hline \multicolumn{6}{|l|}{ Education level [n, \%] } \\
\hline No education & $16(1.43)$ & $3(0.87)$ & $4(1.97)$ & $9(1.57)$ & \multirow[t]{3}{*}{0.094} \\
\hline Primary & $1081(96.52)$ & $330(96.24)$ & $197(97.04)$ & $554(96.68)$ & \\
\hline Secondary/college & $23(2.05)$ & $11(3.19)$ & $2(0.98)$ & $10(1.75)$ & \\
\hline \multicolumn{6}{|l|}{ Occupation [n, \%] } \\
\hline Office worker & $29(2.59)$ & $12(3.49)$ & $4(1.97)$ & $13(2.27)$ & \multirow[t]{3}{*}{0.026} \\
\hline Housewife & $1053(94.02)$ & $312(90.70)$ & $193(95.07)$ & $584(95.64)$ & \\
\hline Other & $38(3.39)$ & $20(5.81)$ & $6(2.96)$ & $12(2.09)$ & \\
\hline \multicolumn{6}{|l|}{ Asthma in family [n, \%] } \\
\hline No & $1105(98.66)$ & $339(98.55)$ & $197(97.04)$ & $569(99.30)$ & \multirow[t]{2}{*}{0.054} \\
\hline Yes & $15(1.34)$ & $5(1.45)$ & $6(2.96)$ & $4(0.70)$ & \\
\hline \multicolumn{6}{|c|}{ Cooking hours and age [mean \pm SD] } \\
\hline Cooking hours per day & $4.23 \pm 1.10$ & $2.31 \pm 0.62$ & $4.04 \pm 1.08$ & $4.45 \pm 0.80$ & $<0.001$ \\
\hline Years cooking & $9.97 \pm 5.12$ & $9.13 \pm 5.28$ & $11.28 \pm 6.04$ & $10.01 \pm 4.54$ & $<0.001$ \\
\hline \multicolumn{6}{|l|}{ Separate Kitchen [n, \%] } \\
\hline Yes & $142(12.67)$ & $70(20.34)$ & $17(8.37)$ & $55(9.59)$ & $<0.001$ \\
\hline \multicolumn{6}{|l|}{ Ventilated kitchen [n, \%] } \\
\hline Yes & $186(16.60)$ & $90(26.16)$ & $25(12.31)$ & $71(12.39)$ & $<0.001$ \\
\hline \multicolumn{6}{|c|}{ Environmental tobacco smoke (ETS) exposure $[\mathrm{n}, \%]$} \\
\hline None & $994(88.75)$ & 309 (89.82) & $180(88.66)$ & $505(88.13)$ & \multirow[t]{4}{*}{0.002} \\
\hline Childhood & $32(2.85)$ & $15(4.36)$ & $5(2.46)$ & $12(2.09)$ & \\
\hline Adulthood & $31(2.76)$ & $14(4.06)$ & $3(1.47)$ & $14(2.44)$ & \\
\hline Both & 63 (5.62) & $6(1.74)$ & 15 (7.38) & $42(7.32)$ & \\
\hline
\end{tabular}

aPrincipal component analysis with varimax rotation was used for computing the SES indices. Based on the distribution of the SES indices, the households were then divided into three groups (tertiles)

models adjusted by age, BMI, education, and socio-economic status, solid biomass fuel use was associated with a $5.5 \%$ decrease in $\mathrm{FEV} 1 / \mathrm{FVC}$ ratio $(\mathrm{AOR}=5.55$; $95 \%$ CI: 3.51-8.78).

Table 6 shows the association between FEV1/FVC ratio with household PM2.5 levels and respondents cooking behavior in a robust multivariable regression model. An interquartile increase in PM2.5 increased the probability of having a low FEV1/FVC ratio by 4.4 percentage points and the ratio declines by $7 \%$ when the PM2.5 levels were above $196.8 \mu \mathrm{g} / \mathrm{m}^{3}$ (> 75th percentile). Respondents having higher cooking ages had 6.9\% lower FEV1/FVC ratio than participants engaged in cooking for less number of years. Similarly, those cooking for four and half hours or more in a day showed a decline in FEV1/FVC ratio by $6.9 \%$ (Table 6 ). The study 


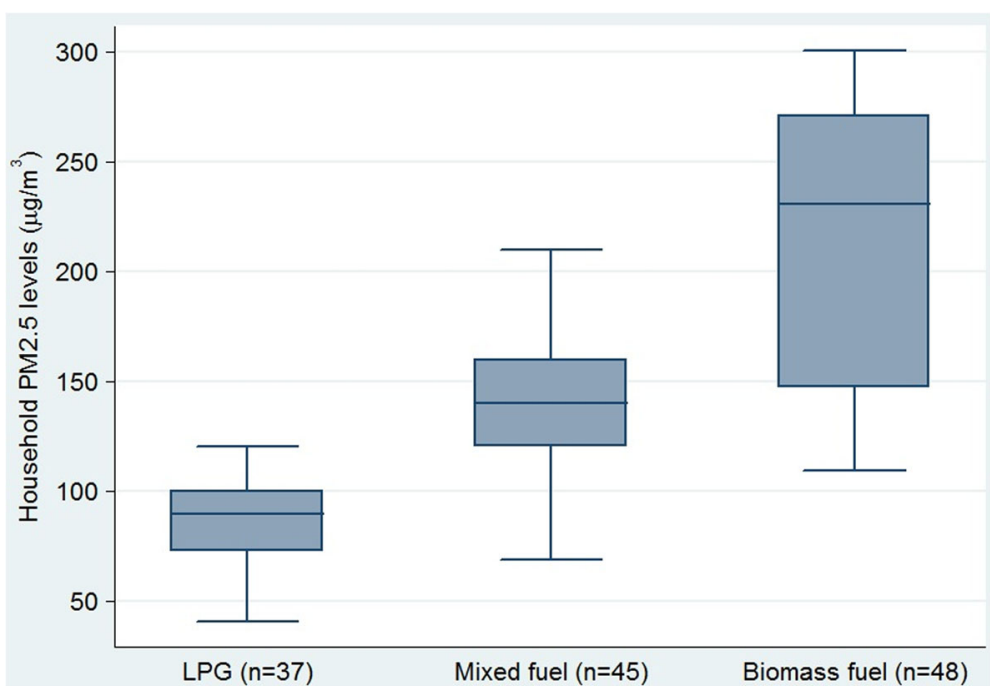

Fig. 2 Box plots comparing average PM2.5 levels in homes $(N=130)$ stratified by cooking fuels: LPG $(n=37)$; Mixed $(n=45)$ and Solid biomass $(n=48)$. [Boxes represent the interquartile range (25th-75th percentiles, median indicated by horizontal line), and whiskers extend to the 5th and 95th percentiles]

showed a strong association between household air pollution (PM2.5 levels) and AFO (lower FEV1/FVC ratio) (Table 6).

\section{Discussions}

To our knowledge, this is the first population-based epidemiological study in Odisha, India to report on the relationship between household cooking behavior and household air quality and its association with $\mathrm{CB}$ as well as with AFO using spirometry data. We also demonstrated a significant decline in lung function with exposure to higher household PM2.5 concentration among never-smoking women in India. The association was robust and insensitive to potential confounders such as age, BMI, education and socio-economic status.
Prevalence of chronic bronchitis in our study was nearly twice than that reported in the earlier nationwide Indian study (INSEARCH), conducted in hospital settings with a reported prevalence of chronic bronchitis of $2.7 \%$ among women older than 35 years [9]. A significant finding of our study is that the overall prevalence of AFO on spirometry is $22.4 \%$ (nearly one-fifth of the total study population). Such a finding has considerable implications, highlighting the phenomenal burden of obstructive lung disease in India likely obscured by what has been, until this study, a lack of accurate epidemiological measurement methods. As demonstrated by the study results, the definition of $\mathrm{CB}$ has a weak correlation with the prevalence of spirometric evidence of AFO and underestimates the true prevalence of obstructive lung diseases in the community. As a formal physician

Table 2 Prevalence of self-reported respiratory symptoms among respondents stratified by household fuel use

\begin{tabular}{|c|c|c|c|c|c|}
\hline Respiratory symptoms ${ }^{a}$ & $\begin{array}{l}\text { All Participants } \\
(N=1120)\end{array}$ & $\begin{array}{l}\text { Liquefied petroleum gas user } \\
(n=344)\end{array}$ & $\begin{array}{l}\text { Mixed fuel user } \\
(n=203)\end{array}$ & $\begin{array}{l}\text { Solid biomass fuel user } \\
(n=573)\end{array}$ & $p$-value \\
\hline Wheeze & $114(10.18)$ & $22(6.40)$ & $19(9.36)$ & $73(12.74)$ & 0.008 \\
\hline Cough at night & $138(12.32)$ & $43(12.50)$ & $21(10.34)$ & $74(12.91)$ & 0.628 \\
\hline Cough in morning & 179 (15.98) & $55(15.99)$ & $29(14.29)$ & $95(16.58)$ & 0.746 \\
\hline Phlegm in morning & $191(17.05)$ & $57(16.57)$ & $30(14.78)$ & $104(18.15)$ & 0.525 \\
\hline Chronic bronchitis $^{\mathrm{b}}$ & $82(7.32)$ & $15(4.36)$ & $17(8.37)$ & $50(8.73)$ & 0.040 \\
\hline Morning breathlessness & 189 (16.88) & $48(13.95)$ & $42(20.69)$ & $99(17.28)$ & 0.119 \\
\hline Breathlessness on exertion & $172(15.36)$ & $49(14.24)$ & $38(18.72)$ & $85(14.83)$ & 0.331 \\
\hline Chest tightness on dust exposure & 206 (18.39) & $55(15.99)$ & $33(16.26)$ & $118(20.59)$ & 0.150 \\
\hline Physician diagnosed asthma ${ }^{c}$ & $59(5.27)$ & $12(3.49)$ & $13(6.40)$ & $34(5.93)$ & 0.200 \\
\hline
\end{tabular}

${ }^{\mathrm{a}}$ Values reported in table are $\mathrm{n}(\%)$

${ }^{b}$ Chronic bronchitis: cough with phlegm for more than 3 months in a year for 2 or more consecutive years

${ }^{\mathrm{C}}$ Physician-diagnosed asthma was defined as participants had been diagnosed with asthma and use of anti-asthmatic medication 
Table 3 Multiple logistic regression analysis of association between household fuel use and chronic bronchitis $(N=1120)$

\begin{tabular}{|c|c|c|c|}
\hline \multirow[t]{2}{*}{ Household fuel use } & \multicolumn{2}{|c|}{ Odds ratios $(95 \% \mathrm{Cl})$} & \multirow{2}{*}{$\begin{array}{l}p \\
\text { value }\end{array}$} \\
\hline & Unadjusted & Adjusted $^{a}$ & \\
\hline Liquefied petroleum gas & 1 (reference) & 1 (reference) & \\
\hline Mixed fuel & $2.00(0.97-4.10)$ & $1.85(0.87-3.89)$ & 0.105 \\
\hline Solid biomass fuel & $2.09(1.15-3.79)$ & $1.96(1.06-3.64)$ & 0.031 \\
\hline
\end{tabular}

${ }^{a}$ Adjusted for age, BMl, socio-economics status, and education

assessment was not involved in the study, we cannot derive the exact diagnoses in the non-CB patients. Nevertheless, these findings lay the groundwork for further research in understanding the accurate epidemiology of obstructive lung diseases in India. Another significant finding that is highlighted is the fact that spirometry must be incorporated as an essential investigation tool in field epidemiological studies of obstructive lung diseases in order to understand the true burden of the problem. We plan to undertake a detailed physician-based assessment of the patients with evidence of AFO on spirometry so that the follow-up data in this regard can provide us useful information in the future.

In our study, as expected, household PM2.5 particle concentrations were higher in homes using biomass fuel than in homes using LPG (Fig. 2). The average PM2.5 levels measured in the living room of the study participants using solid biomass fuel for cooking were three times greater than those of LPG burning households $\left(81.5 \mu \mathrm{g} / \mathrm{m}^{3}\right)$. The mixed fuel users were also found to be exposed to higher PM2.5 in the household air $\left(134.2 \mu \mathrm{g} / \mathrm{m}^{3}\right)$. Our findings are similar to previous reports of household PM2.5 particle concentrations from biomass fuel use [31-34]. In Nepal, the average PM2.5 concentration in biomass burning kitchens was found to be $656 \mu \mathrm{g} / \mathrm{m}^{3}$ [31]. In China, biomass fuel burning is

Table 4 Prevalence of airway obstruction based on spirometry performance among respondents stratified by household fuel use $(N=1056)$

\begin{tabular}{|c|c|c|c|c|c|}
\hline $\begin{array}{l}\text { Lung } \\
\text { function } \\
\text { indices }^{a}\end{array}$ & $\begin{array}{l}\text { All } \\
\text { Participants } \\
(N=1056)\end{array}$ & $\begin{array}{l}\text { Liquefied } \\
\text { petroleum } \\
\text { gas user } \\
(n=319)\end{array}$ & $\begin{array}{l}\text { Mixed } \\
\text { fuel } \\
\text { user } \\
(n=202)\end{array}$ & $\begin{array}{l}\text { Solid } \\
\text { biomass } \\
\text { fuel user } \\
(n=535)\end{array}$ & $p$-value \\
\hline $\begin{array}{l}\text { FEV1/FVC } \\
<70 \% \\
\text { predicted }\end{array}$ & $237(22.4)$ & $25(7.84)$ & $46(22.77)$ & $166(31.03)$ & $<0.001$ \\
\hline $\begin{array}{l}\text { FEV1/FVC } \\
<70 \% \text { and } \\
\text { FEV1 }<80 \% \\
\text { predicted }\end{array}$ & $103(9.75)$ & $9(2.82)$ & $21(10.4)$ & 73 (13.64) & $<0.001$ \\
\hline $\begin{array}{l}\text { FEV1/FVC } \\
<70 \% \text { and } \\
\text { FEV1 }<50 \% \\
\text { predicted }\end{array}$ & $23(2.17)$ & $2(0.18)$ & $6(0.56)$ & $15(1.42)$ & $<0.001$ \\
\hline
\end{tabular}

${ }^{a}$ Values reported in table are $\mathrm{n}(\%)$
Table 5 Multiple logistic regression analysis of association between household fuel use and airflow obstruction ( $N=1056)$

\begin{tabular}{|c|c|c|c|}
\hline \multirow[t]{2}{*}{ Household fuel use } & \multicolumn{2}{|c|}{ Odds ratios $(95 \% \mathrm{Cl})$} & \multirow{2}{*}{$\begin{array}{l}p \\
\text { value }\end{array}$} \\
\hline & Unadjusted & Adjusted $^{\mathrm{a}}$ & \\
\hline Liquefied petroleum gas & 1 (reference) & 1 (reference) & \\
\hline Mixed fuel & $3.46(2.05-5.85)$ & $3.47(2.04-5.90)$ & $<0.001$ \\
\hline Solid biomass fuel & $5.29(3.38-8.27)$ & $5.55(3.51-8.78)$ & $<0.001$ \\
\hline
\end{tabular}

contributed to personal average 24-h exposure to PM2.5 ranged from 22 to $634 \mu \mathrm{g} / \mathrm{m}^{3}$ in winter and from 9 to $492 \mu \mathrm{g} / \mathrm{m} 3$ in summer [32]. Another study in China reported personal exposures to PM2.5 concentrations ranging (Geometric mean) $225-289 \mu \mathrm{g} / \mathrm{m}^{3}$ during the burning of wood or plant materials. In Indian households that used solid fuels, the mean 24-h concentration of PM2.5 was found to be $163 \mu \mathrm{g} / \mathrm{m}^{3}$ (95\% CI: 143,183; median 106; IQR: 191) in the living area.

Our reported prevalence of chronic bronchitis among women is in the range of other reports in India and elsewhere. In our study, the risk of chronic bronchitis among biomass fuel users was significantly higher than in users of LPG or mixed fuel. An Indian study in southern parts of the country reported that biomass fuel users have a higher risk of COPD than the clean fuel users at $2.5 \%$ vs. $2 \%$ [35]. Another study conducted in eastern parts of India reported that women who used biomass fuel are reported to have a higher risk of COPD than LPG fuel users at $4.6 \%$ vs $0.9 \%$ [36].

The biomass fuel users had a lower FEV1/FVC ratio in our study population. We observed a statistically significant association of household PM2.5 concentration and change in lung function indices. A qualitative comparison can be made with other studies which have reported that exposure to biomass smoke is associated with reduced lung function and respiratory symptoms as seen in Guatemala [13, 37], Brazil [38], Malawi [39], Mexico [16], and India [35, 36]. A randomized exposure study in Guatemala reported $\mathrm{CO}$ in exhaled breath was associated with lower lung function in FEV1. The study found that a $10 \%$ increase in $\mathrm{CO}$ was associated with $3.33 \mathrm{~mL}$ of FEV1 [37]. The Mexican study reported that biomass fuel was associated with increased production of phlegm (27 vs. 9\%) and reduced FEV1/FVC ratio (79.9 vs. $82.8 \%$ ) [16]. The study also highlighted that in homes with higher PM10 concentration, cough was more common among women who had lower values of FEV1 (odds ratio, 1.7 ; $95 \%$ confidence interval, 1.0-2.8).

A critical finding of our study is the high prevalence (237 of 1120 participants, 22.4\%) of spirometric evidence of AFO in the study population. This highlights that overall nearly one-fifth of the population has obstructive airflow disease, and thus this work raises important 
Table 6 Multivariable robust regression models for predictors of lung function indices (FEV1/FVC ratio) $(N=1056)$

\begin{tabular}{|c|c|c|c|}
\hline \multirow[t]{2}{*}{ Predictors } & \multicolumn{2}{|l|}{$\beta$ coefficients (95\% Cl) } & \multirow{2}{*}{$\begin{array}{l}p \\
\text { value }\end{array}$} \\
\hline & Unadjusted & Adjusted $^{a}$ & \\
\hline \multicolumn{4}{|l|}{ Household PM2.5 $\left(\mu \mathrm{g} / \mathrm{m}^{3}\right)$} \\
\hline $\operatorname{Low}\left(<92.4 \mu \mathrm{g} / \mathrm{m}^{3}\right)$ & 0 (reference) & 0 (reference) & \\
\hline \multicolumn{4}{|l|}{ [<25th percentile] } \\
\hline High $(92.4-196.8$ g/m³) & $-0.098(-0.128--0.069)$ & $-0.044(-0.074--0.013)$ & 0.005 \\
\hline \multicolumn{4}{|l|}{ [25th - 75th percentile] } \\
\hline Higher $\left(>196.8 \mu \mathrm{g} / \mathrm{m}^{3}\right)$ & $-0.117(-0.166--0.068)$ & $-0.070(-0.124--0.015)$ & 0.013 \\
\hline \multicolumn{4}{|l|}{ [> 75th percentile] } \\
\hline \multicolumn{4}{|l|}{ Cooking age } \\
\hline$<5$ years & 0 (reference) & 0 (reference) & \\
\hline $5-15$ years & $-0.082(-0.093--0.071)$ & $-0.028(-0.055--0.000)$ & 0.044 \\
\hline Above 15 years & $-0.122(-0.142--0.102)$ & $-0.069(-0.120--0.019)$ & 0.007 \\
\hline \multicolumn{4}{|l|}{ Cooking hours per day } \\
\hline$<2.5 \mathrm{~h}$ & 0 (reference) & 0 (reference) & \\
\hline $2.5-4 \mathrm{~h}$ & $-0.047(-0.058--0.036)$ & $-0.037(-0.068--0.006)$ & 0.020 \\
\hline$>4 \mathrm{~h}$ & $-0.108(-0.120--0.097)$ & $-0.069(-0.112--0.025)$ & 0.002 \\
\hline \multicolumn{4}{|c|}{ Environmental tobacco smoke (ETS) Exposure } \\
\hline None & 0 (reference) & 0 (reference) & \\
\hline Childhood & $-0.003(-0.031--0.024)$ & $-0.012(-0.051-0.025)$ & 0.510 \\
\hline Adulthood & $-0.021(-0.070--0.026)$ & $0.040(-0.018-0.100)$ & 0.177 \\
\hline Both & $-0.151(-0.177--0.125)$ & $-0.063(-0.123--0.002)$ & 0.041 \\
\hline
\end{tabular}

${ }^{a}$ Adjusted for age, BMI, marital status, education, socio-economic status, kitchen ventilation

questions about most epidemiological studies that have used symptomatic diagnostic criteria for quantifying the burden of lung diseases in India and elsewhere. AFO was found to be greater among solid biomass fuel users (31\%), as approximately one-third of the population with the exclusive cooking use of solid biomass demonstrated spirometric evidence of AFO, indicating that solid biomass use could be a strong risk factor for chronic lung diseases in the Indian population. Given the extent of AFO revealed with spirometric measurement, the study findings suggest that use of only a questionnaire-based assessment of respiratory symptoms grossly underestimates the presence of obstructive lung disease in the Indian population.

We acknowledge some limitations to our study. First, the study is cross-sectional in nature and there could be recall bias in estimation of $\mathrm{CB}$. Second, there is room for improvement in PM2.5 exposure assessment, because we have only accounted for indoor exposures in the living room. Third, we did not account for seasonal variation of both household exposure and outcome assessments. Another limitation includes the non-performance of post-bronchodilator spirometry, as a large difference between spirometry-measured airflow obstruction (FEV1/ FVC ratio $<0.70$ ) and self-reported chronic bronchitis is partly attributable to failure to exclude subjects with non-COPD-related airway obstruction like asthma. A proportion of the participants with spirometric evidence of obstruction may have reversible AFO, signifying the presence of bronchial asthma rather than fixed AFO indicative of COPD. Lastly, we cannot rule out any residual or unmeasured confounding variables in this study.

\section{Conclusions}

The role of household air pollution exposures on health outcomes including $\mathrm{CB}$ and $\mathrm{AFO}$ among never-smoking women is poorly documented. A significant association was observed between environmental exposures (household PM2.5) levels and change in lung function among women in India. Given the challenges in diagnosing lung diseases early in resource-poor settings, our findings have significant public health implications. Our study findings, based on a robust representative sample in resource-poor settings, using a priori specified analyses contribute to strengthening the evidence on the association of environmental exposures and AFO. Never-smoking women exposed to solid biomass smoke reported lower lung function and more frequent cough and phlegm production than did women cooking with LPG. 


\section{Abbreviations}

AFO: Airflow obstruction; BOLD: Burden of obstructive lung disease; CB: Chronic bronchitis; CHV: Community health volunteers; COPD: Chronic obstructive lung disease; ETS: Environmental tobacco smoke; FEV1: Forced expiratory volume in one second; FVC: Forced vital capacity; IUATLD: International union against tuberculosis and lung disease; LPG: Liquified petroleum gas; PM: Particulate matter; SES: Socio-economic status

\section{Acknowledgements}

The authors acknowledge the cooperation of the households during air sampling. We thank Karunakar Panda and Keshab C Pradhan of AIPH, for assistance with household PM measurements and data collection. We sincerely acknowledge the State Pollution Control Board (SPCB), Odisha for providing laboratory support for PM measurements. The authors express their deepest thanks to the community health volunteers of IMMENSE (Impact of maternal, environmental socio-demographic and economic factors on Child health and development) study, without whose help and cooperation this study could not have been carried out.

\section{Funding}

No direct funding was available for conducting this study. However, resources available for the IMMENSE (Impact of maternal, environmental socio-demographic and economic factors on Child health and development) study of the institute (AIPH) was partially used.

\section{Availability of data and materials}

Due to ethical restrictions for maintaining participant confidentiality and privacy, the data (de-identified) underlying this study shall be available to qualified, interested researchers upon request to: bkpadhi@aiph.ac.in

\section{Authors' contributions}

Study conception: AP, BKP. Study design: BKP. Collection of data: AP. Analysis and interpretation of data: All authors. Drafting of the paper: AP. Critical revision of the paper: BKP. Both authors read and approved the final manuscript.

\section{Authors' information}

AP: is a third-year medical student at Rutgers New Jersey Medical School in Newark, NJ. She is also a two-term member of the American Medical Association Student Committee for Global Public Health. She has been selected to participate in the National Institutes of Health Medical Research Scholars Program, during which she plans to continue public health research. BKP: PhD, MPH, Associate Professor at Asian Institute of Public Health, Bhubaneswar, India.

\section{Ethics approval and consent to participate}

Ethical approval for the study was obtained from the Ethical Review Committee (ERC) of the Asian Institute of Public Health (AIPH-ERC Ref No. 09/2013). Informed written consent was obtained from all study participants, and that they were free to withdraw from the study at any point. The survey team also received the cultural competency and confidentiality training by a qualified trainer

\section{Consent for publication}

Not applicable.

\section{Competing interests}

The authors declare that they have no competing interests.

\section{Publisher's Note}

Springer Nature remains neutral with regard to jurisdictional claims in published maps and institutional affiliations.

\section{Author details}

${ }^{1}$ Rutgers New Jersey Medical School, Newark, NJ, USA. ${ }^{2}$ Center for Environmental and Occupational Health, AIPH University, Bhubaneswar, India.
Received: 30 January 2018 Accepted: 12 July 2018

Published online: 27 July 2018

\section{References}

1. Burney $P$, Jarvis $D$, Perez-Padilla R. The global burden of chronic respiratory disease in adults. Int J Tuberc Lung Dis. 2015;19:10-20. Available from: http://openurl.ingenta.com/content/xref?genre=article\&issn=1027$3719 \&$ volume $=19 \&$ issue $=1 \&$ spage $=10$.

2. Salvi S, Apte K, Madas S, Barne M, Chhowala S, Sethi T, Aggarwal K, Agrawal A, Gogtay J. Symptoms and medical conditions in 204912 patients visiting primary health-care practitioners in India: a 1-day point prevalence study (the POSEIDON study). Lancet Glob Heal. 2015;3:e776-84. Available from: http://linkinghub.elsevier.com/retrieve/pii/S2214109X15001527.

3. Dutta S, Deshmukh PR. Prevalence and determinants of self-reported chronic bronchitis among women in rural Central India. Med J Armed Forces India. 2015;71:48-52. [cited 2015 Apr 1] Available from: http://www. pubmedcentral.nih.gov/articlerender.fcgi?artid=4297829\&tool= pmcentrez\&rendertype $=$ abstract.

4. Meek P, Petersen H, Washko GR, Diaz AA, Kim V, Sood A, Tesfaigzi Y. Chronic Bronchitis is Associated with Worse Symptoms and Quality of Life than Chronic Airflow Obstruction. Chest. 2015; [cited 2015 Apr 1]; Available from: http://www.ncbi.nlm.nih.gov/pubmed/25741880.

5. Kim V, Criner GJ. Chronic bronchitis and chronic obstructive pulmonary disease. Am J Respir Crit Care Med. 2013;187:228-37. Available from: http:// www.atsjournals.org/doi/abs/10.1164/rccm.201210-1843Cl\#.Viprk_krLIU.

6. Mejza F, Gnatiuc L, Buist AS, Vollmer WM, Lamprecht B, Obaseki DO, Nastalek P, Nizankowska-Mogilnicka E, Burney PGJ. Prevalence and burden of chronic bronchitis symptoms: results from the BOLD study. Eur Respir J. 2017;50:1700621. Available from: http://erj.ersjournals.com/lookup/doi/10. 1183/13993003.00621-2017.

7. Kim V, Criner GJ. Chronic Bronchitis and Chronic Obstructive Pulmonary Disease. Am J Respir Crit Care Med. 2013;187:228-37. Available from: http:// www.atsjournals.org/doi/abs/10.1164/rccm.201210-1843Cl.

8. Buist AS, Vollmer WM, Sullivan SD, Weiss KB, Lee TA, Menezes AMB, Crapo $\mathrm{RO}$, Jensen RL, Burney PGJ. The Burden of Obstructive Lung Disease Initiative (BOLD): Rationale and Design. COPD. 2005;2:277-83. Available from: http://www.tandfonline.com/doi/full/10.1081/COPD-57610.

9. Jindal SK, Aggarwal AN, Gupta D, Agarwal R, Kumar R, Kaur T, Chaudhry K, Shah B. Indian study on epidemiology of asthma, respiratory symptoms and chronic bronchitis in adults (INSEARCH). Int J Tuberc Lung Dis. 2012;16: 1270-7.

10. Ferkol T, Schraufnagel D, et al. Ann Am Thorac Soc. 2014;11:404-6. Available from: http://www.atsjournals.org/doi/abs/10.1513/AnnalsATS.201311-405PS.

11. Diaz-Guzman E, Mannino DM. Epidemiology and prevalence of chronic obstructive pulmonary disease. Clin Chest Med. 2014;35:7-16. [cited 2015 Feb 2] Available from: http://www.sciencedirect.com/science/article/pii/ S0272523113001445

12. Lopez AD, Shibuya K, Rao C, Mathers CD, Hansell AL, Held LS, Schmid V, Buist S. Chronic obstructive pulmonary disease: current burden and future projections. Eur Respir J. 2006; 27: 397-412. [cited 2014 Dec 9] Available from: http://erj.ersjournals.com/content/27/2/397.short.

13. van Gemert F, Kirenga B, Chavannes N, Kamya M, Luzige S, Musinguzi $P$, Turyagaruka J, Jones R, Tsiligianni I, Williams S, de Jong C, van der Molen T. Prevalence of chronic obstructive pulmonary disease and associated risk factors in Uganda (FRESH AIR Uganda): a prospective cross-sectional observational study. Lancet Glob Heal. 2015;3:e44-51. Open Access article distributed under the terms of CC BY; [cited 2015 Feb 13] Available from: http://www.ncbi.nlm.nih.gov/pubmed/25539969.

14. Forouzanfar $\mathrm{MH}$, Alexander $\mathrm{L}$, Anderson HR, Bachman VF, Biryukov S, Brauer M, Burnett R, Casey D, Coates MM, Cohen A, Delwiche K, Estep K, Frostad JJ, Astha KC, Kyu HH, Moradi-Lakeh M, Ng M, Slepak EL, Thomas BA, Wagner J, Aasvang GM, Abbafati C, Ozgoren AA, Abd-Allah F, Abera SF, Aboyans V, Abraham B, Abraham JP, Abubakar I, Abu-Rmeileh NME, et al. Global, regional, and national comparative risk assessment of 79 behavioural, environmental and occupational, and metabolic risks or clusters of risks in 188 countries, 1990-2013: a systematic analysis for the Global Burden of Disease Study 2013. Lancet. 2015; Available from: http://linkinghub.elsevier. com/retrieve/pii/S0140673615001282

15. Pelkonen M, Notkola I-L, Nissinen A, Tukiainen H, Koskela H. Thirty-Year Cumulative Incidence of Chronic Bronchitis and COPD in Relation to 30Year Pulmonary Function and 40-Year Mortality. Chest. 2006;130:1129-37. 
Available from: http://inkinghub.elsevier.com/retrieve/pii/ S0012369215511495.

16. Regalado J, Pérez-Padilla R, Sansores R, Páramo Ramirez Jl, Brauer M, Paré P, Vedal $S$. The effect of biomass burning on respiratory symptoms and lung function in rural Mexican women. Am J Respir Crit Care Med. 2006;174:9015. [cited 2014 Feb 19] Available from: http://www.ncbi.nlm.nih.gov/ pubmed/16799080.

17. Smith M, Li L, Augustyn M, Kurmi O, Chen J, Collins R, Guo Y, Han Y, Qin J, Xu G, Wang J, Bian Z, Zhou G, Peto R, Chen Z. Prevalence and correlates of airflow obstruction in 317000 never-smokers in China. Eur Respir J. 2014;44:66-77. Available from: http://erj.ersjournals.com/cgi/doi/ 10.1183/09031936.00152413.

18. Pahwa P, Karunanayake CP, Rennie DC, Lawson JA, Ramsden VR, McMullin K, Gardipy PJ, MacDonald J, Abonyi S, Episkenew J-A, Dosman JA. Prevalence and associated risk factors of chronic bronchitis in first nations people. BMC Pulm Med. 2017;17:95. Available from: http://bmcpulmmed.biomedcentral. com/articles/10.1186/s12890-017-0432-4

19. Rogalsky DK, Mendola P, Metts TA, Martin WJ. Estimating the number of low-income americans exposed to household air pollution from burning solid fuels. Environ Health Perspect. 2014;122:806-10. [cited 2015 Apr 1] Available from: http://www.pubmedcentral.nih.gov/articlerender.fcgi?artid= 4123020\&tool=pmcentrez\&rendertype $=$ abstract.

20. Lakshmi PVM, Virdi NK, Sharma A, Tripathy JP, Smith KR, Bates MN, Kumar R. Household air pollution and stillbirths in India: analysis of the DLHS-II National Survey. Environ Res. 2013;121:17-22. [cited 2013 Jun 30] Available from: http://www.ncbi.nlm.nih.gov/pubmed/23375552.

21. Lim SS, Vos T, Flaxman AD, Danaei G, Shibuya K, Adair-Rohani H, Amann M, Anderson HR, Andrews KG, Aryee M, Atkinson C, Bacchus L, Bahalim AN, Balakrishnan K, Balmes J, Barker-Collo S, Baxter A, Bell ML, Blore JD, Blyth F, Bonner C, Borges G, Bourne R, Boussinesq M, Brauer M, Brooks P, Bruce NG, Brunekreef B, Bryan-Hancock C, Bucello C, et al. A comparative risk assessment of burden of disease and injury attributable to 67 risk factors and risk factor clusters in 21 regions, 1990-2010: a systematic analysis for the Global Burden of Disease Study 2010. Lancet. 2012;380:2224-60. [cited 2013 Feb 28] Available from: http://www.thelancet.com/journals/a/article/ PIIS0140-6736(12)61766-8/fulltext.

22. Rehfuess E. Fuel for life: household energy and health. World Heal Organ. 2006;

23. Smith KR, Bruce N, Balakrishnan K, Adair-Rohani H, Balmes J, Chafe Z, Dherani M, Hosgood HD, Mehta S, Pope D, Rehfuess E. Millions dead: how do we know and what does it mean? Methods used in the comparative risk assessment of household air pollution. Annu Rev Public Health. 2014;35: 185-206. [cited 2015 Mar 20] Available from: http://www.ncbi.nlm.nih.gov/ pubmed/24641558.

24. Lancet. Improving air quality starts at home. Lancet. 2014;384:-1821. [cited 2015 Feb 18] Available from: http://www.ncbi.nlm.nih.gov/pubmed/25457903

25. Odisha - National Health Mission. [cited 2014 Nov 30]. Available from: http:// nhm.gov.in/nrhm-instate/state-wise-information.html.

26. Dean A, Sullivan K, Soe M. OpenEpi: Open Source Epidemiologic Statistics for Public Health. Version. www.OpenEpi.com, Updat. 2014/09/22 2015 [cited 2015 Mar 16]. Available from: http://www.openepi.com/Menu/OE_Menu.htm.

27. Burney $P$, Laitinen $L$, Perdrizet $S$, Huckauf $H$, Tattersfield A, Chinn S, Poisson $\mathrm{N}$, Heeren A, Britton JR, Jones T. Validity and repeatability of the IUATLD (1984) Bronchial symptoms questionnaire: an international comparison. Eur Respir J. 1989;2:940-5. [cited 2015 Mar 16] Available from: http://erj. ersjournals.com/content/2/10/940.short.

28. Quanjer PH, Tammeling GJ, Cotes JE, Pedersen OF, Peslin R, Yernault JC. Lung volumes and forced ventilatory flows. Report Working Party Standardization of Lung Function Tests, European Community for Steel and Coal. Official Statement of the European Respiratory Society. Eur Respir J Suppl. 1993;16:540. Available from: http://www.ncbi.nlm.nih.gov/pubmed/8499054

29. Global Initiative for Chronic Obstructive Lung Disease. Global Strategy for the Diagnosis, Management and Prevention of COPD. [cited 2013 May 31]. Available from: http://goldcopd.org/uploads/users/files/GOLD_Report_2013_ Feb20.pdf.

30. Vyas S, Kumaranayake L. Constructing socio-economic status indices: how to use principal components analysis. Health Policy Plan. 2006;21:459-68.

31. Pokhrel AK, Bates MN, Acharya J, Valentiner-Branth P, Chandyo RK, Shrestha PS, Raut AK, Smith KR. PM2.5 in household kitchens of Bhaktapur, Nepal, using four different cooking fuels. Atmos Environ. 2015;113:159-68. Available from: http://www.sciencedirect.com/science/article/pii/S1352231015300649.
32. Baumgartner J, Schauer JJ, Ezzati M, Lu L, Cheng C, J a P, Bautista LE. Indoor air pollution and blood pressure in adult women living in rural China. Environ Health Perspect. 2011;119:1390-5. Available from: http://www. pubmedcentral.nih.gov/articlerender.fcgi?artid=3230444\&tool= pmcentrez\&rendertype $=$ abstract.

33. Hu W, Downward GS, Reiss B, Xu J, Bassig BA, Hosgood HD, Zhang L, Seow WJ, Wu G, Chapman RS, Tian L, Wei F, Vermeulen R, Lan Q. Personal and indoor PM2.5 exposure from burning solid fuels in vented and unvented stoves in a rural region of China with a high incidence of lung cancer. Environ Sci Technol. 2014;48:8456-64.

34. Balakrishnan K, Ghosh S, Ganguli B, Sambandam S, Bruce N, Barnes DF, Smith KR. State and national household concentrations of PM2.5 from solid cookfuel use: results from measurements and modeling in India for estimation of the global burden of disease. Environ. Health. 2013;12:77. [cited 2014 Mar 31] Available from: http://www.pubmedcentral.nih.gov/ articlerender.fcgi?artid $=3851863 \&$ tool $=$ pmcentrez\&rendertype $=$ abstract.

35. Johnson P, Balakrishnan K, Ramaswamy P, Ghosh S, Sadhasivam M, Abirami $\mathrm{O}$, Sathiasekaran BWC, Smith KR, Thanasekaraan V, Subhashini AS Prevalence of chronic obstructive pulmonary disease in rural women of Tamilnadu: implications for refining disease burden assessments attributable to household biomass combustion. Glob. Health Action. 2011;4 Available from: http://www.globalhealthaction.net/index.php/gha/article/view/7226.

36. Mukherjee S, Roychoudhury S, Siddique S, Banerjee M, Bhattacharya P, Lahiri T, Ray MR. Respiratory symptoms, lung function decrement and chronic obstructive pulmonary disease in pre-menopausal Indian women exposed to biomass smoke. Inhal Toxicol. 2014;26:866-72. Available from: http:// www.tandfonline.com/doi/full/10.3109/08958378.2014.965560.

37. Pope D, Diaz E, Smith-Sivertsen T, Lie RT, Bakke P, Balmes JR, Smith KR, Bruce NG. Exposure to household air pollution from wood combustion and association with respiratory symptoms and lung function in nonsmoking women: results from the RESPIRE trial, Guatemala. Environ Health Perspect. 2015;123:285-92. Available from: http://www.pubmedcentral.nih.gov/ articlerender.fcgi?artid $=4384202 \&$ tool $=$ pmcentrez\&rendertype $=$ abstract.

38. da Silva LFF, Saldiva SRDM, Saldiva PHN, Dolhnikoff M. Impaired lung function in individuals chronically exposed to biomass combustion. Environ Res. 2012;112:111-7. [cited 2013 Oct 17] Available from: http://www.ncbi. nlm.nih.gov/pubmed/22136759.

39. Fullerton DG, Suseno A, Semple S, Kalambo F, Malamba R, White S, Jack S, Calverley PM, Gordon SB. Wood smoke exposure, poverty and impaired lung function in Malawian adults. Int J Tuberc Lung Dis. 2011;15:391-8. Available from: http://www.ncbi.nlm.nih.gov/pubmed/21333109.

Ready to submit your research? Choose BMC and benefit from:

- fast, convenient online submission

- thorough peer review by experienced researchers in your field

- rapid publication on acceptance

- support for research data, including large and complex data types

- gold Open Access which fosters wider collaboration and increased citations

- maximum visibility for your research: over $100 \mathrm{M}$ website views per year

At $\mathrm{BMC}$, research is always in progress.

Learn more biomedcentral.com/submissions 